\title{
立地住民の声に共感の声が多く
}

\section{核セキュリティについての記事も好評（10月号のWeb アンケート結果）}

「原子力学会誌」10月号に対して寄せられたWeb アンケートの結果をご紹介します。今回は106名の方から， 回答がありました。

\section{1. 高く評価された記事}

Web アンケートでは，各記事の内容扔よび書き方に ついて，それぞれ5段階で評価していただいています。 10月号で高く評価された記事について，「内容」，「書き 方」に分けてそれぞれ上位 4 件をご紹介いたします。

第 1 表「内容」の評価点の高かった記事(上位 4 件)

\begin{tabular}{|c|c|c|c|}
\hline 順位 & $\begin{array}{c}\text { 記事の } \\
\text { 種類 }\end{array}$ & タイトル & $\begin{array}{c}\text { 評点 } \\
\text { (内容) }\end{array}$ \\
\hline 1 & 時論 & $\begin{array}{l}\text { 日本社会と核セキュリティ } \\
\text { 一原子力の国際展開の中でのセ } \\
\text { キュリティ認識 }\end{array}$ & 4.06 \\
\hline 2 & 講演 & $\begin{array}{l}\text { 立地町の一住民としての思い } \\
\text { 一原子力発電所とともに歩む } \\
\text { 「原子力総合シンポジウム } 2009\rfloor \\
\text { に参加して }\end{array}$ & 3.90 \\
\hline 3 & $\begin{array}{c}\text { 定点 } \\
\text { “感”測 }\end{array}$ & 原子力の“グローバル”展開 & 3.84 \\
\hline 4 & 解説 & $\begin{array}{l}\text { 核拡散をめぐる国際政治 } \\
\text { 一インド，パキスタンの核兵器 } \\
\text { 開発を中心に }\end{array}$ & 3.83 \\
\hline
\end{tabular}

第 2 表 「書き方」の評価点の高かった記事(上位 4 件)

\begin{tabular}{|c|c|c|c|}
\hline 順位 & $\begin{array}{l}\text { 記事の } \\
\text { 種類 }\end{array}$ & タイトル & $\begin{array}{l}\text { 評点 } \\
\text { (書き方) }\end{array}$ \\
\hline 1 & 講演 & $\begin{array}{l}\text { 立地町の一住民としての思い } \\
\text { 一原子力発電所とともに歩む } \\
\text { 「原子力総合シンポジウム2009」 } \\
\text { に参加して }\end{array}$ & 3.83 \\
\hline 1 & $\begin{array}{l}\text { 定点 } \\
\text { “感”測 }\end{array}$ & 原子力の“グローバル”展開 & 3.83 \\
\hline 3 & 巻頭言 & $\begin{array}{l}\lceil マ ニ フ ェ ス ト と \text { 起請文」 } \\
\text { 一政治家は花魁じゃない }\end{array}$ & 3.80 \\
\hline 4 & 時論 & $\begin{array}{l}\text { 日本社会と核セキュリティ } \\
\text { 一原子力の国際展開の中でのセ } \\
\text { キュリティ認識 }\end{array}$ & 3.77 \\
\hline
\end{tabular}

今月は, 時論, 講演が好評でした。
2. 自由記入欄の代表的なコメント，要望等

(1) 最近, NHK で「知られざる原発解体」が放送され たが，番組の制作に当たっている方が，原子力を視 聴者にどのように伝えたいと思っているのか，ま た，製作担当者は原子力をどの程度理解して番組を 作っているのかを知りたいと思う。製作者と専門家 の対談のような記事があったら良い。

(2) 最近の学会誌は読んだ内容について, 周辺の人に 内容を気軽に話せる記事が多くなった。自分への知 識だけでなく，周辺の人に話題提供できるように なってきたことは，原子力への理解を広めるために も有用である。

（3）報告「企業に扔ける女性のキャリアの磨き方」に関 して，よい集会であったと思う。女子が特別でなく， しかし男子と同じでなくそれぞれのよさを発揮し て，より良い職場を作っていけることがなによりで ある。

\section{3. 編集委員会からの回答}

(1) 上記(2)のコメントに対して, 今後も, 会員への話 題提供ができるような記事を企画していきたいと思 います。

学会誌ではこれからも, 会員の皆様により質の高い情 報を送りたいと考えております。記事に対する評価はも とより,さまざまな提案もぜひ, Web アンケートで扮 寄せ下さるようお願いいたします。 